\title{
ECOBIOLOGICAL CONTEXT OF HOME VISITS FROM THE PERSPECTIVE OF USERS IN THE MUNICIPALITY OF ARACAJU, STATE OF SERGIPE - SE, BRAZIL
}

\author{
CONTEXTO ECOBIOLÓGICO DA VISITA DOMICILIAR SOB A PERSPECTIVA DOS \\ USUÁRIOS NO MUNICÍPIO DE ARACAJU/SE
}

\author{
Leane de Carvalho MACHADO ${ }^{1}$; Andrea Gomes de Santana MELO ${ }^{2}$ Cláudia Moura MELO $^{3}$ \\ 1. Enfermeira, Mestre em Saúde e Ambiente, Universidade Tiradentes - UNIT, Aracaju, SE, Brazil; 2. Enfermeira, Mestre em Saúde e \\ Ambiente, Universidade Federal do Piauí - UFPI, Picos, PI, Brazil; 3. Bióloga, Doutora em Parasitologia, Docente do Programa de Pós- \\ graduação em Saúde e Ambiente, Universidade Tiradentes - UNIT, Aracaju, SE, Brazil.
}

\begin{abstract}
A quantitative study was conducted in the municipality of Aracaju/State of Sergipe - SE, Brazil, to construct and analyse the ecomap of users (216 users) who received a home visit from the Family Health Teams (Equipes de Saúde da Família). The study showed that half of the users $(50.5 \%)$ were over 60 years old, $77.8 \%$ were female, $68.0 \%$ had a low educational level, $49.1 \%$ were retired, $83.3 \%$ reported being bedridden, $53.2 \%$ reported a chronic injury as the reason for having the visit, $62.5 \%$ did not know the nursing assistant professional, $58.8 \%$ had a family caregiver, $94.4 \%$ considered the visit important, and $75.9 \%$ were informed about their right to a visit but considered it a privilege. The home visit is perfectly feasible, humanising and welcoming; it is a unique opportunity to immerse into and get to know the environment of families, delivering services in a more humane and welcoming space.
\end{abstract}

KEYWORDS: Echogram. Home visit. Family Health Team.

\section{INTRODUCTION}

Home visits (HV) play a major role in health care, as they allow one to evaluate the environmental and physical conditions in which individuals and their families live, to assist and apply control measures both for communicable and parasitic diseases and for non-communicable diseases, and, especially, to educate (KAWAMOTO et al., 1995). Despite being an old procedure, HV bring innovative results, as they allow one to know the reality of users and their families in loco and to strengthen the bonds between users, therapists and healthcare professionals (SOUZA et al., 2004).

$\mathrm{HV}$ are an instrument that allows one to get to know the family and the lifestyle and work of its members, the solidarity patterns that develop within the family environment and how the patterns can contribute to caring, curing or recovering one of its members. HV also include understanding the social, economic, ideological factors of the family and your workforce in the society (SOUZA et al., 2004; SAVASSI; DIAS, 2006). The National Primary Care Policy (Política Nacional de Atenção Básica PNAB) describes the working process of Family Health Teams (FHTs) as directing the practice towards "extended family care, effective through the knowledge of the structure and functionality of families, which aims to propose interventions that influence health-disease processes of individuals, families and their own community" (BRASIL, 2006a; RODRIGUES et al., 2011).
The present study aimed to characterize the user profile of $\mathrm{HV}$, in addition to constructing and analyzing an ecomap from the perspective of these users in the city of Aracaju, State of Sergipe, Brazil.

\section{MATERIAL AND METHODS}

The present is a quantitative and descriptive study on Public Health performed in the municipality of Aracaju, capital of the state of Sergipe, located in the northeast region of Brazil, with a population of 570,937 inhabitants (ARACAJU, 2009; IBGE, 2010). Users that had a HV from healthcare professionals of the 128 FHTs, which covered $97.31 \%$ of the population during the year of 2010, participated in the study.

The Municipal Health Department of Aracaju/SE organised the healthcare activities and services into basic or primary healthcare. To facilitate the organisation of the service, the municipality was divided into eight health regions; each region has five to six Health Units, and each Unit has one to six FHTs, totalling 128 FHTs (ARACAJU, 2010).

The number of teams was used to establish the sample because of unavailable data regarding HV. The sample was selected randomly and proportionally using the formula proposed by Barbetta (1999), with 10 FHTs and $100 \%$ of users from these teams being studied, which corresponded to 216 users. An acceptable sampling error of $10 \%$ and a confidence interval of $95 \%$ were used. A 
percentage of $15 \%$ was added to the calculated total as a strategy to prevent possible losses of subjects and/or data. One team from the $1^{\text {st }}, 3^{\text {rd }}, 4^{\text {th }}, 5^{\text {th }}, 6^{\text {th }}$ and $7^{\text {th }}$ regions and two teams from the $2^{\text {nd }}$ and $8^{\text {th }}$ regions were randomly selected, considering that these latter two regions had a greater number of FHTs, totalling 10 FHTs.

Data were collected by an interview conducted in the home of the users, complying with Resolution no. 196/96 of the National Health Council of the Ministry of Health, following previous authorisation from the Municipal Health Secretariat of Aracaju and evaluation and approval of the project by the Ethics and Research Committee of UNIT (registration no. 161208).

The criteria adopted for the inclusion of users were being over 18 years of age, being registered as a user of the Family Health Team, having an $\mathrm{HV}$ during the studied year and agreeing to participate in the study; not being registered as users of the FHT studied, not having a $\mathrm{HV}$ in the studied year, moving to a different region, death or not agreeing to participate in the study were the exclusion criteria.

The study used a semi-structured form validated by the face validity method, with twenty questions that accepted one or multiple responses. The numerical variables are described as the mean and standard deviation, whereas simple frequencies and proportions are used for categorical variables. The following variables related to the profiles of users: age group, gender, income, integration into the labour market, diagnosis and perception of the importance of the HV. We investigated these variables and established relationships between them.

The analysis of the distribution of classes within a categorical variable in the sample was performed using the binomial test for a single proportion. The significance level adopted was 0.05 , and we assumed that the tests were two-tailed.

The ecomap is a diagram that depicts the relationships between family and community, identifying existing relationships, whether they are supportive or weak connections and whether they are considered strained by conflicts between the family and the world. The ecomap demonstrates the resource flow or the lack of resources and deprivations (ROCHA et al., 2002).

In the ecomap, HV users are represented in the centre of the circle. The lines indicate the type of connection: continuous lines represent strong bonds, and dotted lines represent weak bonds. The thickness of the line and the number of lines express the intensity/regularity of bonds.

\section{RESULTS}

The HV users studied in the municipality of Aracaju/SE consisted of 216 individuals with a mean age of $56.1 \pm 25.6$ years. The minimum age was 13 years, and the maximum age was 103 years, with a predominance of females $(77.8 \%$; $p<0.0001)$, showing that the FHTs visit adolescents, adults and elderly people (Table 1).

Table 1. Characterisation of users treated at home by Family Health Team professionals in the municipality of Aracaju/SE.

\begin{tabular}{llcc}
\hline User Characteristics & & $\%(\mathrm{n})$ & Accumulated \% (n) \\
\hline Age & $0-9$ & - & - \\
& $10-19$ & $5.0(11)$ & $5.0(11)$ \\
& $20-59$ & $44.5(96)$ & $49.5(107)$ \\
& $\geq 60$ & $50.5(109)$ & $100.0(216)$ \\
Gender & & \\
& Female & $77.8(168)$ & $77.8(168)$ \\
Educational Level & $22.2(48)$ & $100.0(216)$ \\
& Male & & \\
& Illiterate & $36.1(78)$ & $36.1(78)$ \\
& Incomplete primary education & $32.0(69)$ & $68.1(147)$ \\
& Primary education & $10.6(23)$ & $78.7(170)$ \\
& Secondary education & $18.5(40)$ & $97.2(210)$ \\
& Incomplete Higher education & $1.4(3)$ & $98.6(213)$ \\
& Higher education & $1.4(3)$ & $100.0(216)$ \\
& & \\
Family Income & < MW & $9.3(20)$ & $9.3(20)$ \\
& 1 MW & $33.3(72)$ & $42.6(92)$ \\
& 2 MW & $34.7(75)$ & $77.3(167)$
\end{tabular}




\begin{tabular}{llcc}
\hline & 3 MW & $12.5(27)$ & $89.8(194)$ \\
& Unknown & $9.7(21)$ & $99.5(215)$ \\
& & $0.5(1)$ & $100.0(216)$ \\
Insertion in the & Retired & & \\
labour market & Unemployed & $49.1(106)$ & $49.1(106)$ \\
& Formal job & $31.0(67)$ & $80.1(173)$ \\
& Others & $7.4(16)$ & $87.0(189)$ \\
& & $12.5(27)$ & $100.0(216)$ \\
\hline Living in the & Less than 1 year & & \\
current household & 1 and 5 years & $2.8(6)$ & $2.8(6)$ \\
& 5 and 15 years & $27.8(60)$ & $30,6(66)$ \\
& 15 and 20 years & $18.5(40)$ & $49,1(106)$ \\
& over 20 years & $9.3(20)$ & $58,4(126)$ \\
& & $41.7(90)$ & $100,0(216)$ \\
\hline
\end{tabular}

Legend: MW - minimum wage

The present study showed that only $24.5 \%$ of the visited households had 5 rooms. The ratio between numbers of rooms/users showed that $25 \%$ had up to 1 room per person, $50 \%$ had up to 1.3 rooms per person and $75 \%$ had up to two rooms per person.
According to ecomap, $65.3 \%$ of the users had a caregiver, most of whom are family members, and about one-third of the users do not have caregivers. (Figure 1).

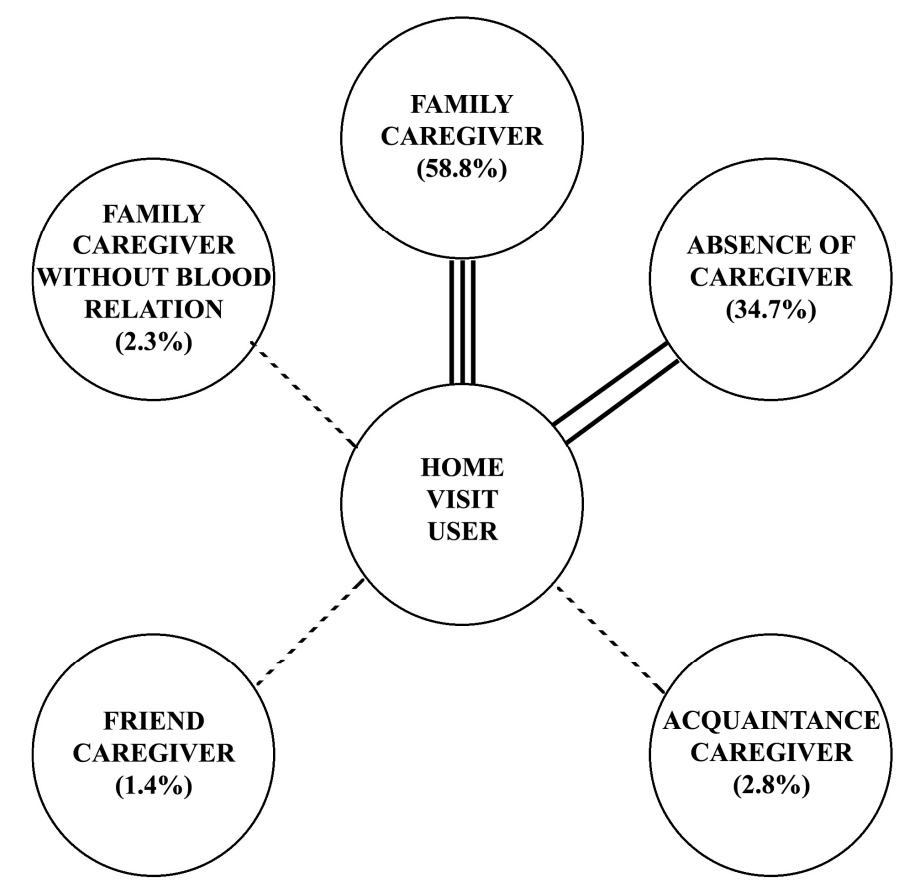

Figure 1. Ecomap of the relationship between home visit users and their caregivers in the municipality of Aracaju/SE, 2009

Evaluating the users' frequency of $\mathrm{HV}$ in the health unit (HU) it was verified that the majority $(63.4 \%)$ had not been in an $\mathrm{HU}$ for at least 6 months, and of these, $13.9 \%$ had never been in any HU. During the analysis of the perception of HV users in Aracaju, it was found that $99.5 \%$ of them consider HV important, and $94.4 \%$ feel satisfied to have $\mathrm{HV}$, as reported by a user: "We feel confident and more valued".

When asked about their rights to HV, due to the impossibility of going to the unit and needing health care, most answered that they knew about this right and that they had received previous information about HV (Table 2). 
Table 2. Perceptions of users about HV in the municipality of Aracaju/SE.

\begin{tabular}{llcc}
\hline Users' perception & & $\%(\mathrm{n})$ & Accumulated \% (n) \\
\hline Perception about HV & Good (satisfied) & $94.4(204)$ & $94.4(204)$ \\
\cline { 2 - 4 } & Bad (embarrassed) & $1.4(3)$ & $95.8(207)$ \\
\cline { 2 - 4 } & Another perception & $4.2(9)$ & $100.0(216)$ \\
\cline { 2 - 4 } & & & \\
\hline Knowledge \\
Right to the HV & Yes & $75.9(164)$ & $75.9(164)$ \\
\cline { 2 - 4 } & No & $24.1(52)$ & $100.0(216)$ \\
\cline { 2 - 4 } & \multicolumn{3}{c}{$70.4(152)$} \\
\hline HV scheduled & Previously notified & $70.4(152)$ & $92.6(200)$ \\
\cline { 2 - 4 } & Not notified & $22.2(48)$ & $97.7(211)$ \\
\cline { 2 - 4 } & Sometimes & $5.1(11)$ & $100.0(216)$ \\
\hline
\end{tabular}

When asked about the reason for having $\mathrm{HV}$, most of the answers indicated hypertension/diabetes, followed by postpartum women, orthopaedic problems and disabilities. When the responses of users were compared with the main reasons that the population should have $\mathrm{HV}$, the majority of the answers reported being bedridden, follow by disabled, postpartum period and undergone surgery. It was observed that users identified their diseases, but they did not express being bedridden or disabled as the reason for the visit (Table 3). In the present study, users that had limited mobility were considered "disabled", and all factors able to interfere with the health of the population were considered "social problems".

Table 3. Frequency distribution of health problems or conditions that restrict HV, according to the perspective of users in the municipality of Aracaju/SE.

\begin{tabular}{lcc}
\hline $\begin{array}{l}\text { Health condition/Reason for } \\
\text { the home visit }\end{array}$ & $\begin{array}{c}\text { User Population \% } \\
(\mathrm{n})\end{array}$ & $\begin{array}{c}\text { Interviewed User } \\
\%(\mathrm{n})\end{array}$ \\
\hline Elderly/Bedridden & $83.8(181)$ & $\mathrm{nm}$ \\
Hypertension & $\mathrm{nm}$ & $53.2(115)$ \\
Diabetes & $\mathrm{nm}$ & $53.2(115)$ \\
Postpartum/NB & $57.4(124)$ & $34.7(75)$ \\
Orthopaedic problems & $\mathrm{nm}$ & $19.9(43)$ \\
Disability & $70.8(153)$ & $11.6(25)$ \\
Surgery & $56.9(123)$ & $1.9(4)$ \\
Accident & $\mathrm{nm}$ & $1.9(4)$ \\
Social Problem & $22.2(48)$ & $2.3(5)$ \\
Others & $17.1(37)$ & $13.9(30)$ \\
\hline
\end{tabular}

Legend: NB (newborn); nm (not mentioned)

Among the reasons given by users for not having $\mathrm{HV}$ by professionals, $48.6 \%$ of doctors, $56.5 \%$ of nurses and $46.3 \%$ of agents did not make the visit due to lack of time. Among assistants, the reasons reported were labour strikes, administrative problems, lack of time, not wanting to make the visit, not liking to make the visit, "being lazy", etc.
Although HV should be performed by all members of the FHT, according to the interviewed families, it was observed that Community Health Agents (CHAs) are the main personnel responsible for home follow-up, since the majority reported to know these professionals. This was followed by nurses, doctors and nursing assistants, as can be observed in the echogram (Figure 2). 


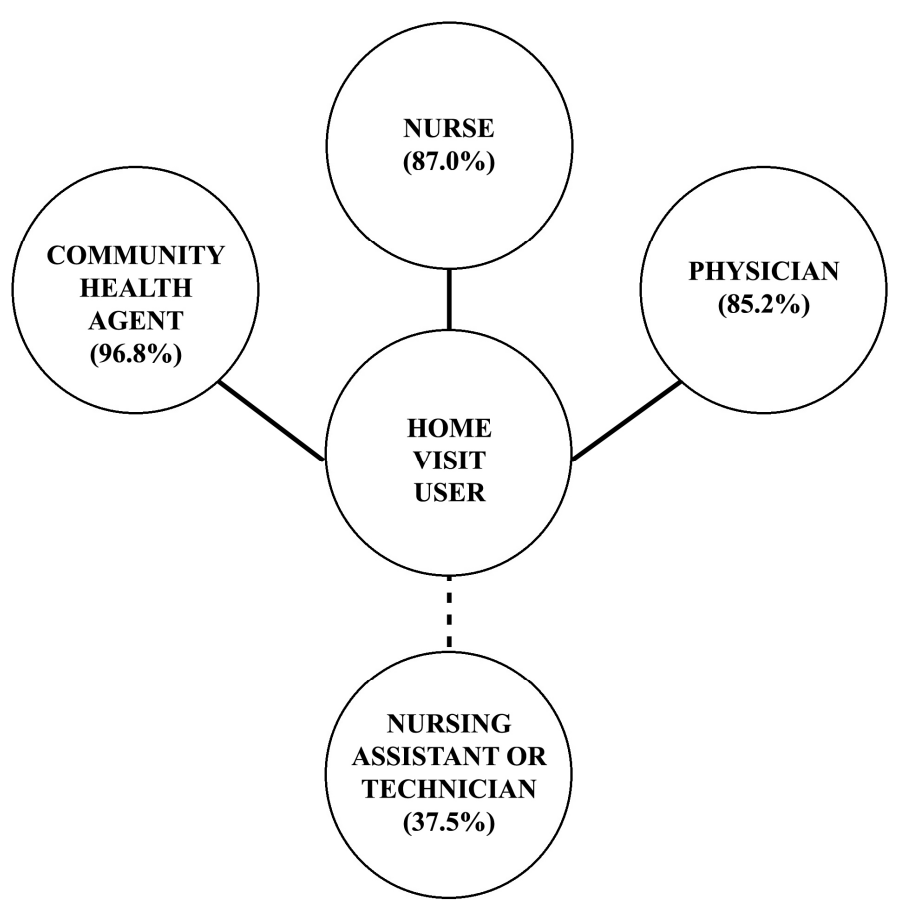

Figure 2. Ecomap of the existence/relationship between professionals from Family Health Teams and users of $\mathrm{HV}$ in the municipality of Aracaju/SE.

In the municipality of Aracaju/SE, 78.2\% $(169 / 216)$ of users reported that their family members were not treated during $\mathrm{HV}$.

In total, $65.7 \%$ of users reported that $\mathrm{CHA}$ visits occur monthly, $15.7 \%$ occur biweekly, and $2.8 \%$ occur daily, which shows that $\mathrm{HV}$ are regular for $84.2 \%$ of users; $14.4 \%$ of users have $\mathrm{HV}$ at an interval greater than once a month, and $1.4 \%$ said that a CHA does not visit. It means that although $96.8 \%$ of users know the CHA, $14.4 \%$ of users from the territory have not been receiving monthly visits, and $1.4 \%$ have not been receiving a visit at all.

\section{DISCUSSION}

Most users served by HV were in the age group over 50 years. A study performed in southern Brazil showed that these users had some financial difficulties and limitations in performing daily activities and sexual; they continuously used medication and had good access to healthcare. The authors concluded that it is possible to have a good quality of life even with comorbidities (JOSIANE et al., 2009).

Studies conducted in different regions of Brazil showed significant differences with regard to access to healthcare services and showed that women use these services more regularly than men use the services, both for medical and dental appointments (PINHEIRO et al., 2002). This observation reflects the situation described in studies performed by the Ministry of Health in
Brazil, which showed that men were more susceptible to health issues, especially chronic diseases, and that they die earlier than women, combined with the fact that men do not seek primary healthcare (BRASIL, 2009a).

When analyzing the educational level of HV users in the city of Aracaju / SE, only $29.1 \%$ had completed primary and secondary education. The other users, most of them, were illiterate or did not have complete formal education. This educational level profile agrees with a study performed in the state of Tocantins in 2003, where most visits were for users with no or poor educational levels, many of which were considered functionally illiterate. Low educational levels and occupational skills are associated with social problems such as violence and may cause chronic health problems with physical sequelae (MARASQUIN et al., 2004; SANTANA et al., 2005; IRIART et al., 2008).

When we observe the family income, it is verified that a large part of the families present average salary above a minimum wage, varying between one and less than two minimum wages. The results from the present study are consistent with the study performed in the municipality of Natal, state of Rio Grande do Norte, which showed that the family income of users was concentrated at up to twice the minimum wage, showing socioeconomic fragility. This finding is different from a study in the municipality of Palmas, state of Tocantins (NEVES et al., 2004), which showed that $92 \%$ of users had an income of up to twice the 
minimum wage. It should be noted that a study performed in Brazil showed that the lower the income, the lower the access to healthcare services and the greater the number of bedridden people (DIMENSTEIN et al., 2005; SOUSA et al., 2007; NÉRI; SOARES, 2002).

The profile of $\mathrm{HV}$ users in the labour market in the present study showed a predominance of retired and unemployed persons, as well as a very low percentage of employees in the formal labour market. Several studies show an increasing number of unemployed people, unregistered workers and informal workers, and these individuals are more prone to accidents and incidents (SANTANA et al., 2005; IRIART et al., 2008). Conversely, HV are prioritised for users of the Public Health System (Sistema Único de Saúde - SUS), especially for informal workers and retired people, who are largely excluded from other types of health services (MARASQUIN et al., 2004).

Once the Family Health Strategy proposed by the government elects a family as a target social nucleus in a defined territory, it is essential to evaluate all the environmental variables of the homes of these users (COSTA; CARBONE, 2009).

The way of life of users must be known, and HV provide this information by permitting knowledge of the existence of family bonds and how they can contribute to the care, recovery or cure of the user that needs the visit (SOUZA et al., 2004; SAVASSI; DIAS, 2006).

The low number of rooms per person is a socioeconomic factor that contributes to the health issues of users because the family piles up in a few rooms, especially when a resident is with infectious disease (ALVES, 2004). This condition affects the maintenance of the health of residents because the physical space is decreased, which directly affects meeting basic human needs.

A study conducted by the Brazilian Institute of Geography and Statistics - IBGE (ALVES, 2004) showed that the density of residents per room has been falling over the years, which indicates greater availability of rooms per person and better comfort. However, interviewees were not asked about the sizes of the rooms; therefore, home spaces may be decreased or better used (ALVES, 2004; PINTO et al., 2004).

Among the HV users interviewed, more than half lived for more than 15 years in the same residence. Time living in the same household is a factor that facilitates the work of FHTs that care for users and their families, allowing FHT workers to know the family structure and functionality continuously over time, coordinate care, establish bonds and take responsibility for these households.

Caregivers must be identified by the team professionals, and their resilience must be determined, encouraging and strengthening this capacity. Caregivers must be capable of helping people and families, especially those facing enduring adversity, such as the existence of family members who are bedridden, have limited mobility and/or are carriers of chronic degenerative diseases. The professionals from the FHTs must facilitate and/or guide lay home caregivers with regard to the minimum primary care tasks in the household, such as personal hygiene care, waste disposal, feeding the patient, medication administration, dressings and knowledge of signs and symptoms of complications.

A study conducted in the municipalities of the south, southeast and northeast regions of Brazil showed that most caregivers are family members (FEUERWERKER; MERHY, 2008). Some municipalities in the countryside of São Paulo have approved an ordinance that creates a home assistance service in which one of the criteria for receiving this service is the existence of a caregiver in the household (SÃO JOSÉ DO RIO PRETO, 2007).

In present study, nearly two-thirds of $\mathrm{HV}$ users had not been in a HU in the past six months, with one-tenth of those users never having been to a health unit. This indicates that the vast majority of HV have been conducted to meet the needs of users with limited mobility and of bedridden users with health issues.

A study conducted in Goiânia showed that most users like to have HV. It is a moment that allows them to be assisted, ask questions, receive explanations and be valued as a human being; the professional listens to their complaints and difficulties and becomes a friend-professional (SANT'ANA et al., 2001). Regarding the knowledge of their rights, this is the ideal moment to empower the users, disclosing how they can participate in SUS negotiation and agreement spaces, whether in conferences or health councils, given that information and knowledge are essential goods of the population (PELLEGRINI FILHO, 2004).

It is important to let the family know in advance about HV to overcome difficulties that range from stopping work and interrupting household tasks performed by the family members to a waste of time and money with the displacement of the professional and the absence of a caregiver to receive guidelines (SOUZA et al., 2004). On the other hand, it considered whether the previous 
schedule of HV can interfere with the observation of social reality of users.

Diabetes appears as one of the main reasons for the user to receive $\mathrm{HV}$. The assistance to diabetic users (Table 3) involves different strategies, such as multidisciplinary consultation, drug treatment, adoption of healthy habits and participation in educational groups. Thus, guidance and the adoption of self-care practices, characterised by low adherence, especially due to limited mobility, are necessary (Table 3). In these cases, $\mathrm{HV}$ and the use of a Conversation Map, a game-like tool created by the International Diabetes Federation (FERNANDES et al., 2010), emerges as one caring strategy allowing the recognition/mapping of theme categories related to feelings, knowledge about the disease, following the food/physical activity plan and barriers to self-care practices (TORRES et al., 2014).

Another relevant aspect is that only $34.7 \%$ of users mentioned childbirth as a reason for having an HV. An FHT must monitor up to 4,000 inhabitants, with 3,000 as the recommended mean, and approximately $2 \%$ of the population is expected to be pregnant; therefore, approximately 600 postpartum women annually should have a postpartum HV (BRASIL, 2006b; ARACAJU, 2008). However, this data shows that probably not performing VD and / or location of not visited postpartum women should be the absence of registration form and monitoring of the visits performed and to be performed.

Home Visits are important to the women even if they participated in individual and collective activities during prenatal care at the health unit because it allows them to clarify persistent questions about the postpartum period and the newborn, such as breast care and umbilical stump care.

In southern Brazil, pregnant women monitored by community health agents (CHAs) begin their prenatal care earlier, have a greater number of consultations and clinical and laboratory examinations and receive more guidance on breastfeeding and ferrous sulphate supplementation, showing the importance of this modality of care (CESAR et al., 2008). A study performed in Chile showed that HV have been used as an excellent strategy of intervention for pregnant adolescents, through a home health aides to educate, to decrease the stress of the family and to help develop self-help abilities using the available resources (CHEREAU et al., 2001). In our study, postpartum women represented $34.7 \%$ (75) of those identified (Table 2).

The health of women and children are program areas of critical importance that were established in Brazil in the 1930s and were prioritised in the Health Pact (Pacto de Saúde) and in the PNAB (BRASIL, 2004; 2006b; 2007). When a woman becomes pregnant condition for postpartum, she must feel confident enough to assume the role of a mother. Nursing influences the postpartum women/newborn pair by providing guidance and explanations, by decreasing anxiety and by minimising difficulties, especially regarding breastfeeding, the child's health record card, subsequent visits or consultations and physiological restoration of the woman (RODRIGUES et al., 2006).

The PNAB considers ten healthcare areas to be a priority, including chronic non-communicable diseases such as hypertension and diabetes (BRASIL, 2006a). Previous data are consistent with the established national policy, showing that $53.2 \%$ of $\mathrm{HV}$ users are hypertensive and/or diabetics. Often, for an effective control of their diseases, these users also need regular and continuous use of medications. Briefly, the social medicalisation process can be seen as the progressive expansion of the intervention field of biomedicine through the redefinition of human experiences and behaviours as if they were medical problems.

The use of medication is essential for good disease control, but other factors are important and should be considered for contributing to good health management, such as healthy eating, physical activity, leisure and stress reduction, which are also factors that may lead to uncontrolled health issues. When living in a society that values anaesthesia and sedation of symptoms, doctors and their patients learn to stifle the inherent question to any pain or disease: What is not well? For how much longer? Why is it necessary? Why me? Conversely, doctors who stay completely deaf to the implicit question in the complaint of patients may recognise symptoms and make correct diagnoses but will not understand anything about their suffering (TESSER, 2006).

We observed a lack of knowledge about nursing assistants by users, indicating a possible distance between this professional and the other members of the team and users. The role of these professionals should be recovered in the team, making the community perceive them, know them and identify them as a team member, as well as understand their responsibilities.

A similar result regarding CHAs was found in a study performed in the municipality of Vitória da Conquista, State of Bahia - BA, Brazil, which found that $\mathrm{CHAs}$ make visits at least once per month, according to $87.8 \%$ of interviewees (TEIXEIRA, 2004). 
The user-healthcare professional relational aspect in HV performed by FHTs in Aracaju is a favourable factor, given that in other regions of northeast Brazil, the difficulty with dialog and the lack of communication are so evident that a gap is created between users and professionals, causing a paralysis in communication (ALBUQUERQUE; BOSI, 2009).

One of the main activities of the Family Health strategy is to register families in the territory and care for individuals and families longitudinally. The work process of the teams must begin with the definition of a service territory and the practice of extended home healthcare and knowing the families (BRASIL, 2006a). It is a healthcare model focused on health surveillance, and the care must be comprehensive, with activities for health promotion, disease prevention, treatment, follow-up and rehabilitation by the multidisciplinary team.

Another important aspect of $\mathrm{HV}$ is the fact that it is an activity aimed at families, allowing for a type of action aimed at solving problems in real life situations, in the family environment (COSTA, 1977). Thus, it is an activity fundamentally characterised by the interaction between individuals, users-caregivers-family members-healthcare professionals, and thus, communication is vital to the health-disease aspect.

In Aracaju, where this study was conducted, most HV users reported that their relatives were not treated during HV. This is an opportunity to think about the humanization of care, comprehensive care, meeting family health needs during HV, not wasting opportunities and at the same time reducing the number and time of users attending health facilities (ALBUQUERQUE; BOSI, 2009).

In relation to the frequency of $\mathrm{HV}$, at least one visit is prescribed in the PNAB for each family, and this is a health indicator agreed annually by all Brazilian municipalities (BRASIL, 2006a; BRASIL, 2009b). However, although $96.8 \%$ of HV users in Aracaju know CHA, slightly more than one tenth of them still do not receive monthly visits and a small percentage did not receive CHA visits. Based on this information, we highlight that the nurse must perform a better follow-up of the work conducted by the CHA, verify and update family records, and observe whether the number of inhabitants in the territory of the CHA is consistent with the established policy or if the territory should be remapped so that the $\mathrm{CHA}$ can monitor every family. ANDRADE et al. (2014) also indicated the implementation of an instrument to record and monitor individuals and families that are HV users
(B-VD form) in the municipality of Aracaju, after collective validation performed by professionals from the Family Health Strategy.

In this sample, it was observed that $\mathrm{HV}$ were performed mainly to intervene or minimise the health-disease process, caring for and treating diseases that the users already have, and much less to promote the health of healthy users, which is consistent with studies performed in the state of Tocantins (TAKAHASHI; OLIVEIRA, 2001; MARASQUIN et al., 2004; NEVES et al., 2004).

\section{CONCLUSION}

The present study helped characterise HV users in the municipality of Aracaju, identified some aspects of their lives, verified that most of them are elderly and showed that chronic diseases have made it impossible or difficult for them to walk. An ecomap allowed us to analyse the relationship between users and caregivers and verify that there is an inexpressive participation of friends and acquaintances in the healthcare of $\mathrm{HV}$ users in Aracaju. The ecomap of the relationship between users and the team's healthcare professionals showed that strategies to give visibility to nursing assistants of the FHT must be established.

According to the reports by HV users, it was possible to observe the appreciation of the doctor at the expense of other healthcare professionals as well as the medicalisation of healthcare, showing the need to strengthen the bond with all team professionals, in addition to the importance of other methods, such as diet and physical activity, to help control diseases.

The home visit is a tool capable of expanding the access of the population to healthcare measures and is a unique opportunity to immerse in the environment where users and their families live, providing a different perspective by knowing the locus of life of the population, expanding interactions and interventions, knowing their weaknesses, capturing their needs, understanding the limitations of each household and providing care in a single space, with humanisation and solidarity (bonds of confidence and co-responsibility), either through measures for health promotion, disease prevention, treatment, monitoring or rehabilitation. Due to its complexity, the HV is a challenge, and it is necessary to continue investing in strengthening this practice through the preparation and awareness of FHT professionals, who would need to be available and have a personal predisposition to perform HV. 
RESUMO: Estudo quantitativo realizado no município de Aracaju/Se que objetivou a construção e análise de ecomapa do universo de usuários (216 usuários) que receberam visita domiciliar das Equipes de Saúde da Família. O estudo revelou que metade dos usuários $(50,5 \%)$ tinham mais de 60 anos, 77,8\% eram do gênero feminino, 68,0\% com baixa escolaridade, $49,1 \%$ aposentados; $83,3 \%$ relataram o fato de estarem acamados e 53,2\% referiram agravo crônico como motivo para receber a visita, 62,5\% desconheciam o profissional auxiliar de enfermagem, 58,8\% tinham cuidador familiar, 94,4\% consideravam a visita importante e 75,9\% foram informados do direito a visita, mas a consideravam um privilégio. A visita domiciliar é perfeitamente exequível, humanizadora e acolhedora; é uma oportunidade ímpar de imergir e conhecer o ambiente das famílias, prestando atendimento em espaço mais humano e acolhedor.

PALAVRAS-CHAVE: Ecograma. Visita domiciliar. Equipe de Saúde da Família.

\section{REFERENCES}

ALBUQUERQUE, A.B.B.; BOSI, M.L.M. Visita domiciliar no âmbito da Estratégia Saúde da Família: percepções de usuários no Município de Fortaleza, Ceará, Brasil. Cad. Saúde Pública, v. 25, n. 5, p. 11031112, 2009. http://dx.doi.org/10.1590/S0102-311X2009000500017

ALVES, J.E.D. As Características dos domicílios brasileiros entre 1960 e 2000. Textos para discussão. n. 10 Escola Nacional de Ciências Estatísticas. Rio de Janeiro: CDDI/IBGE, 2004. 40 p.

ANDRADE, A.M.; GUIMARÃES, A.M.D.N; COSTA, D.M.; MACHADO, L.C.; GOIS, C.F.L. Visita domiciliar: validação de um instrumento para registro e acompanhamento dos indivíduos e das famílias. Epidemiol. Serv. Saúde, v. 23, n. 1, p. 165-175, 2014. doi: 10.5123/S1679-49742014000100016

ARACAJU. Prefeitura Municipal de Aracaju. Apresenta aspectos geográficos da cidade de Aracaju.

Aracaju; 2009 Disponível em: http://www.aracaju.se.gov.br/aracaju/?act=fixo\&materia=aspectos_geograficos

ARACAJU. Secretaria Municipal de Saúde. Modelo Saúde e Cidadania. Coordenação de Saúde da Mulher. Manual de Ações Programáticas. Aracaju (SE). 2008.

ARACAJU. Secretaria Municipal de Saúde (SMS) Aracaju/Sergipe. Modelo Saúde e Cidadania. Aracaju (SE). 2010. www.aracaju.se.gov.br/saude.

BARBETTA, P.A. Estatística aplicada as ciências sociais. $3^{a}$ ed. Florianópolis: UFSC, 1999. 286 p.

BRASIL. Ministério da Saúde. Secretaria de Atenção à Saúde. Departamento de Ações Programáticas Estratégicas. Política nacional de atenção integral à saúde da mulher: princípios e diretrizes. Brasília (DF), Ministério da Saúde. 2004.

BRASIL, Ministério da Saúde. Secretaria de Assistência à Saúde. Política Nacional de Atenção Básica. Brasília (DF), Ministério da Saúde. 2006a.

BRASIL. Ministério da Saúde. Secretaria Executiva. Departamento de Apoio à descentralização. Diretrizes operacionais dos Pactos pela Vida, em Defesa do SUS e de Gestão. 76 p. - Série A. Normas e manuais Técnicos. Brasília (DF), Ministério da Saúde. 2006b.

BRASIL. Ministério da Saúde. Secretaria de Atenção à Saúde. Departamento de Ações Programáticas estratégicas. Política Nacional Atenção Integral à de Saúde da Mulher. Brasília (DF), Ministério da Saúde. 82p., 2007.

BRASIL. Ministério da Saúde. Instrutivo dos indicadores do Pacto pela Saúde. Brasília (DF), Ministério da Saúde. 2009a. 
BRASIL. Ministério da Saúde. Secretaria de Assistência à Saúde. Departamento de Ações Programáticas Estratégicas. Política Nacional de Atenção Integral à Saúde do Homem. Princípios e Diretrizes. Brasília (DF), Ministério da Saúde. 2009b.

CESAR, J.A.; MENDOZA-SASSI, R.A.; ULMI, E.F.; DALL'AGNOL, M.N. NEUMANN, N.A. Diferentes estratégias de visitas domiciliar e seus efeitos sobre assistência pré natal no extremo sul do Brasil. Cad. saúde Pública, v. 24, n. 11, p. 2614 - 2622, 2008. http://dx.doi.org/10.1590/S0102-311X2008001100016.

CHEREAU, B.M.; SILVA, C.B.; ALVAREZ, M.A. Una perspectiva integradora del embarazo adolescente: la visita domiciliaria como estratégia de intervención. Rev. Psicol., v. 10, n. 1, p. 21-34, 2001.

https://revistas.uchile.cl/index.php/RDP/article/download/18526/19557/

COSTA, E.M.A.C.; CARBONE, M.H. Saúde da família: uma abordagem multidisciplinar. 2 ed. Rio de Janeiro: Ed. Rúbio, 2009. 260 p.

COSTA, J. Visitação domiciliária - Base para o ensino de enfermagem na comunidade. Rev. enferm. novas dimensões, v. 3, n. 2, p. 78-82, 1977.

DIMENSTEIN, M.; SANTOS, Y.F.; BRITO, M.; SEVERO, A.K.; MORAIS, C. Demanda em saúde mental em unidades de saúde da família. Mental, v. 3, n. 5, p. 33-42, 2005. http://pepsic.bvsalud.org/pdf/mental/v3n5/v3n5a03.pdf

FERNANDES, O.D.; WORLEY, A.V.; BEATON, S.J.; GLASRUD, P. Educator experience with the U.S. Diabetes Conversation Map ${ }^{\circledR}$ Education Program in the Journey for Control of Diabetes: The IDEA Study. Diabetes Spectr., v. 23, n. 3, p. 194-198, 2010. doi:10.2337/diaspect.23.3.194

FEUERWERKER, L.C.M.; MERHY, E.E.A contribuição da atenção domiciliar para a configuração de redes substitutivas de saúde: desinstitucionalização e transformação de práticas. Rev. Panam. Salud Publica, v. 24, n. 3, p. 180-188, 2008. http://dx.doi.org/10.1590/S1020-49892008000900004

INSTITUTO BRASILEIRO DE GEOGRAFIA E ESTATÍSTICA [IBGE]. Censo 2010. Rio de Janeiro (RJ). 2010. https://ww2.ibge.gov.br/home/estatistica/populacao/censo2010/tabelas_pdf/total_populacao_sergipe.pdf IRIART, J.A.B.; OLIVEIRA, R.P.; XAVIER, S.S.; COSTA, M.A.S.; ARAÚJO, G.R.; SANTANA, V.S. Representações do trabalho informal e dos riscos à saúde entre trabalhadoras domésticas e trabalhadores da construção civil. Ciênc. saúde coletiva, v. 13, n. 1, p. 165-174, 2008. http://dx.doi.org/10.1590/S141381232008000100021

JOSIANE, J.M.; SCHNEIDER, D.G.; COELHO, F.L.; NASCIMENTO, E.R.P.; LUIZ, G. Avaliação da qualidade de vida de idosos que recebem cuidados domiciliares. Acta Paul. Enferm., v. 22, n. 3, p. 265-271, 2009. http://dx.doi.org/10.1590/S0103-21002009000300005

KAWAMOTO, E.E.; SANTOS, M.C.M.; MATTOS, T.M. Enfermagem comunitária. São Paulo: EPU, 1995. 200p.

MARASQUIN, H.G.; DUARTE, R.V.C.; PEREIRA, R.B.L.; MONEGO, E.T. Visita domiciliar: o olhar da comunidade da quadra 603 Norte. Palmas (TO). Rev. UFG (on line), v. 6, n. Especial, 2004.

https://teste.proec.ufg.br/revista_ufg/familia/H_visita.html

NÉRI, M.; SOARES, W. Desigualdade social e saúde no Brasil. Cad. Saúde Pública, v. 18 (Suplemento), p. S77-S87, 2002. http://dx.doi.org/10.1590/S0102-311X2002000700009

NEVES, C.F.; CAVALCANTE, J.P.R.; BEZERRA, J.I.A.; PEREIRA, J.F.; PITTERI, J.S.M.; BARBOSA, M.A. Percepções da população sobre o programa saúde da família em Palmas-TO. Rev. UFG (on line), v. 6, n. Especial, 2004. https://teste.proec.ufg.br/revista_ufg/familia/D_percepcao.html 
PELLEGRINI FILHO, A. Pesquisa em saúde, política de saúde e equidade na América Latina. Ciênc. saúde coletiva, v. 9, n. 2, p. 339-350, 2004. http://dx.doi.org/10.1590/S1413-81232004000200011

PINHEIRO, R.S.; VIACAVA, F.; TRAVASSOS, C.; BRITO, A.S. Gênero, morbidade, acesso e utilização de serviços de saúde no Brasil. Ciênc. saúde coletiva, v. 7, n. 4, p. 687-707, 2002. http://dx.doi.org/10.1590/S1413-81232002000400007

PINTO, K.D.B.P.C.; MAGGI, R.R.S.; ALVES, J.G.B. Análise de risco sócio-ambiental para comprometimento pleural na pneumonia grave em crianças menores de 5 anos. Rev Panam. Salud Publica, v. 15, n. 2, p. 104109, 2004. http://dx.doi.org/10.1590/S1020-49892004000200005

ROCHA, S.M.M.; NASCIMENTO, L.C.; LIMA, R.A.G. Enfermagem pediátrica e abordagem da família: subsídios para o ensino de graduação. Rev. Latino-Am. Enfermagem, v. 10, n. 5, p. 709-714, 2002. http://dx.doi.org/10.1590/S0104-11692002000500013

RODRIGUES, D.P.; FERNANDES, A.F.C.; SILVA, R.M.; RODRIGUES, M.S.P. O Domicílio como espaço educativo para o autocuidado de puérperas- binômio mãe e filho. Texto Contexto Enferm., v. 15, n. 2, p. 277 286, 2006. http://dx.doi.org/10.1590/S0104-07072006000200012

RODRIGUES, T.M.M.; ROCHA, S.S.; PEDROSA, J.I.S. Visita domiciliar como objeto de reflexão. Revista $\begin{array}{lllllllll}\text { Interdisciplinar NOVAFAPI, } & \text { v. } & 4, & \text { n. } & 3, & \text { p. } & 44-47, & 2011 .\end{array}$ https://edisciplinas.usp.br/pluginfile.php/444770/mod_folder/content/0/Visita\%20domiciliar\%20como\%20obje to $\% 20 \mathrm{de} \% 20$ reflexao\%20-\%20 complementar.pdf?forcedownload=1

SANT'ANA, E.R.R.B.; TAIA, L.; MEDEIROS, M. O significado de visita domiciliar para usuários de um programa de diálise peritoneal ambulatorial contínua (CAPD) em Goiânia. Rev. Eletr. Enf. (on line), Goiânia, v. 3, n. 2, 2001. https://www.revistas.ufg.br/fen/article/view/727

SANTANA, V.; NOBRE, L.; WALDVOGEL, B.C. Acidentes de trabalho no Brasil entre 1994 e 2004: Uma revisão. Ciênc. saúde coletiva, Rio de Janeiro, v. 10, n. 4, p. 841-855, out-dez. 2005. http://dx.doi.org/10.1590/S1413-81232005000400009

SÃO JOSÉ DO RIO PRETO. Secretaria Municipal De Saúde. Portaria no 37/2007. Dispõe sobre a implantação e regulamentação do Serviço Municipal de Atenção Domiciliar - SAD, São José do Rio Preto (SP). 2007.

SAVASSI, L.C.M.; DIAS, M.F. Visita Domiciliar. Grupo de Estudos em Saúde da Família. AMMFC: Belo Horizonte, 2006. http://www.smmfc.org.br/gesf/gesf_vd.htm.

SOUSA, A.J.F.; MATIAS, G.N.; GOMES, K.F.A.; PARENTE, A.C.M. A saúde mental no Programa de Saúde da Família. Rev. bras. enferm., Brasília, v. 60, n. 4, p. 391-395, jul.-aug. 2007. http://dx.doi.org/10.1590/S0034-71672007000400006

SOUZA, C.R.; LOPES, S.C.F.; BARBOSA, M.A.A Contribuição do Enfermeiro no Contexto de Promoção à Saúde através da visita domiciliar. Rev. UFG (on line), v. 6, n. Especial, 2004.

https://teste.proec.ufg.br/revista_ufg/familia/G_contexto.html

TAKAHASHI, R.F.; OLIVEIRA, M.A.C. A visita domiciliária no contexto da saúde da família. In BRASIL. USP; MINISTÉRIO DA SAÚDE (org.) Manual de Enfermagem. Brasília: Ministério da Saúde, 2001, p. 4346.

TEIXEIRA, S.A. Avaliação dos usuários sobre o Programa de Saúde da Família em Vitória da Conquista Bahia - Brasil. In: FERNANDES, A.S.; SECLEN-PALACIN, J.A. (orgs.). Projeto de desenvolvimento de sistemas e serviços de saúde. Experiências e desafios da atenção básica e saúde familiar: caso Brasil. Brasília: OPAS; 2004. p. 77-101. http://www.saude.mt.gov.br/arquivo/2944 
TESSER, C.D. Medicalização social (I): o excessivo sucesso do epistemicídio moderno na saúde. Interface Comunic, Saúde, Educ, v. 10, n. 19, p. 61-76, 2006. http://dx.doi.org/10.1590/S1414-32832006000100005

TORRES, H.C.; SANTOS, L.M.; CORDEIRO, P.M.C.S. Home visit an educational health strategy for selfcare in diabetes. Acta paul. enferm., v. 27, n. 1. p. 23-28, 2014. http://dx.doi.org/10.1590/19820194201400006 